\title{
THE FACTORS AFFECTING THE ENVIRONMENTAL INFORMATION REPORTING OF LISTED COMPANIES IN VIETNAM
}

\author{
NGUYEN THI MAI HUONG ${ }^{1}$, NGUYEN THI KIM TUYEN, DO KHANH LY ${ }^{2}$ \\ ${ }^{1}$ Banking University Ho Chi Minh City, ${ }^{2}$ Industrial University of Ho Chi Minh City; \\ huongntm@buh.edu.vn,nguyenthikimtuyen@qnu.edu.vn,dokhanhly@iuh.edu.vn
}

\begin{abstract}
The success of many organizations depends on the level of resource ownership, the real value of the expertise, the research and development activities, the interaction with the environment and society where they operate ... Thus, the description of resources according to the traditional expression of financial statements (FS) of Vietnamese enterprises has not met the demand of using information of stakeholders in the integration trend. Therefore, the paper is designed to analyze the factors affecting environmental information disclosure and propose solutions to enhance the responsibility for environmental performance, to meet the compliance with international practices and increasing the transparency of the stock market in Vietnam in the spirit of Circular 155/2015 / TT-BTC of listed enterprises.
\end{abstract}

Keywords. Environmental information, environmental reports, environmental accounting,...

\section{INTRODUCTION}

The enterprises are using the environmental information report (EIR) as a tool to express their awareness (Sumiani, Haslinda and Lehman, 2007) when meeting the legal requirements, satisfying the needs of the Stakeholders, improve relationships with customers, investors and employees ... create competitive advantages, increase turnover, then improve financial results, improve reliability and usefulness to the Stakeholders (Gray and partners, 2001; Hackston and Milne 1996). For nearly 25 years, this topic has received a lot of attention from researchers and operating enterprises. Such as:

Approach by information disclosure method: Roberta Salomone and Giulia Galluccio (2001) in the study "Environmental issues and financial reporting trends in the petroleum and chemical industry" conducted the research about annual reports of 82 chemical and petroleum companies from the year 1993 to 1998 , in particular 26 companies in the US and Canada, 26 companies in Northern Europe, 26 companies in Southern Europe and 4 companies from other countries showed $92.1 \%$ of selected companies already brought the EIR into the annual report, in which $100 \%$ of companies from the United States or Canada are subject to strict environmental regulations, followed by $96.2 \%$ Northern Europe, finally Southern Europe. Despite few environmental regulations, the publication rate is still quite high at $86.8 \%$. Sumiani, Haslinda and Lehman (2007) conducted a study of 50 leading Malaysian public companies from various NCNs listed on the Bursa Malaysia Stock Exchange in the fiscal year of 2003. The results show that the level of EIR in annual reports of Malaysian companies are quite low, showing general information or qualitative information. The most reported information is about the existence of an environmental management system, environmental policies in enterprises. This study also concluded that the ISO certificate of environmental management system has influenced on voluntary environmental reporting.

Approach according to disclosed environmental information: Currently, there is no separate international accounting standard to mention environmental information, which is scattered directly and indirectly in many different standards (Elena M. Barbu, Pascal Dumontier, Niculae Feleagă and Liliana Feleagă, 2014). The international accounting standards for environmental information such as IAS 1, IAS 8, IAS 20, IAS 37 and IAS 41, IFRS 6, IFRIC 5 were analyzed in the study of CA Mohammad Firoz, Prof. . A. Aziz Ansari (2010). Or in the article "Environmental accounting and international financial reporting standards" also noted a number of accounting standards related to the environment and in each accounting standard has indicated the relevant paragraph and have accompanying explanations such as: 

IAS 37, IAS 38, IAS 39, IAS 41, IFRIC 5. Recently, a more complete study published by Barbu et al (2014) has identified 19/65 international accounting standards related to recognition and measurement this issue represents assets, liabilities and environmental costs.

Specifically, 13/29 IASs (IASs1,2,8,10,12,16,20,32,36,37,38,39 and 41); 5/9 IFRSs (3,6,7,8 and 9) and 3/6 reports explaining financial reporting - IFRICs (IFRICs 1,5 and 6). The author has presented some important information in each of the standards to improve the EIR related to recognition, measurement and disclosure of costs, liabilities, assets and environmental income. The standards that have a direct impact on EIR are IFRS 6, IAS 36, IAS 38, IAS 16, IAS 37, IAS 2, IAS 20, IAS 8, IFRIC 1, IFRIC 5, IFRIC 6. The standards that have a indirect impact on EIR are IAS 1, IAS 10, IAS 12, IAS 32, IAS 39, IAS 41, IFRS 7, IFRS 8, IFRS 9

Approach according to the relationship between disclosed industry and the business results: Anup Kumar Saha, Shahnag Akter (2012) studied the annual report of 20 companies in the pharmaceutical and chemical industries; cement, ceramics, textile and garment; food and related listed industries on the Dhaka Stock Exchange in Bangladesh in 2009 or 2010 indicated that there are 9 companies (45\%) voluntarily EIR in annual reports, averaging only $2.33 \%$ of environmental information is published in the form of qualitative information, without quantitative information. Among 9 EIR companies on annual reports, there are 4 companies $(44.44 \%)$ in pharmaceutical and chemical sectors, 3 companies $(33.33 \%)$ from cement industry and 2 companies $(22,22 \%)$ came from the textile and garment industry and food industries. In addition, with 15 types of environmental information given by the author in the study, nearly $47 \%$ of the information is not published. All 9 companies (100\%) announced their concerns about environmental issues reflected in environmental policies, 4 companies (44.44\%) announced emissions information or preserved natural resources, 3 companies $(33.33 \%)$ reported on setting up wastewater treatment plants or pollution control equipment. or program of afforestation and land reclamation and only 1 company (11.11\%) has the certificate of environmental management system (ISO 14001). Therefore, research shows that Bangladesh companies's EIR is still in its infancy and needs further development. At the same time, it has proved a positive relationship between EIR and company profits when EIR companies have higher profitability than unpublished companies. Nguyen and Thu (2017) assess the impact of EIR and KTMT (environmental accounting) on Vietnamese enterprises' ability to access finance on the basis of investigating 104 foreign investors working in Thang Long, Quang Minh and Noi Bai industrial parks. The results show that EIR has a strong influence on the decision of foreign investors, thus affecting the ability of enterprises to access foreign capital. The importance of KTMT (environmental accounting) information in ascending order is the timeliness of information, the reliability of information, the completeness of the information. However, the article only focuses on assessing the demand for management accounting information of foreign investors without analyzing the factors affecting the level of EIR in general.

The studies were conducted in different contexts but all showed the trend of increasing published environmental information to meet the increasing environmental awareness of the community. Vietnam is a developing country, in the process of deep integration into the world economy. Vietnam's stock market is in the transition phase to complete the legal framework to enhance transparency of the EIR for listed companies, so the need for closer approach to international practices in EIR is inevitable.

\section{BUILDING THE RESEARCH MODEL}

\subsection{Research hypothesis \\ Community pressure (ALCD)}

According to the legal framework, ALCD has impact on the EIR. The growth in awareness and concern of the community about environmental issues forces companies to take measures to ensure that their business is acceptable by the community. Business managers seek the way to legitimize activities through assessment, monitoring and control of activities that cause environmental impacts to maintain the legality of the organization in the eyes of the community. The enterprise accounting system will be 
renewed to enhance the interpretation of environmental information to reinforce community awareness or attention redirection in adverse environmental situations (Patten, 1992; Tilt, 1994, Deegan and Rankin, 1996). Xianbing Liu and V. Anbumozhi (2009) have shown that environmental information has a positive relationship with the company's operating position when companies listed in the east coast in China has more ability to disclose emissions data because the community awareness of the environment is relatively higher in those areas. Therefore, the authors set up the first hypothesis about the relationship between CP and the level of EIR.

Hypothesis 1(H1): ALCD has a positive relationship with the level of EIR of listed companies on Vietnam stock market.

\section{Stakeholder pressure (ALBLQ)}

The enterprises need to meet the demand of EIR for stakeholders to improve and enhance their relationships with stakeholders as well as build their good image and brand. Stakeholder theory says the different stakeholders require different types of environmental information, for example: the company managers need information about costs, revenues and profits or the environmental organizations and communities require information on environmental impacts, while tax authorities, shareholders and investors need relevant information about environmental assets and liabilities. Deegan and Gordon (1996) find evidence of the correlation between EIR and environmental lobbying organizations. The lack of stakeholder engagement is predicted a low level of EIR.

Hypothesis 2 (H2): The ALBLQ has a positive relationship with the level of EIR of listed companies on Vietnam stock market.

\section{Pressure of coercion (ALCP)}

According to the institutional theory framework, in Vietnam, the tightening of legal regulations from the government, state agencies on the environment, especially the environmentally sensitive industries forces the enterprises to increasingly comply with many regulations on environmental information to ensure transparency and meeting the requirement of sustainable development such as: (1) Law on environmental protection No. 55/2014/QH13 was approved by the National Assembly of the Socialist Republic of Vietnam on June 23, 2014, (2) Mineral Law No. 60/2010/QH12 on November 17, 2010, (3) Circular 38/2015/TT-BTNMT on environmental rehabilitation and restoration in mineral exploitation activities on June 30, 2015 and other legal documents ... The regulations of the Government, the Ministry of Finance and the Ministry of Natural Resources and Environment can significantly shape the behavior of enterprises on EIR. For the above reasons, it can be seen that ALCP has an impact on the EIR. Therefore, the authors build the next hypothesis:

Hypothesis 3 (H3): ALCP of the Government has a positive relationship with the level of EIR of listed companies on the Vietnam Stock Market.

\section{Normative pressure (ALQP)}

Under the framework of institutional theory, ALQP has an impact on KTMT (environmental accounting) practices in general and the EIR in particular. In order to be able to practice EIR, it is required that the accountant of the company must have knowledge and skills related to the recognition, measurement, presentation and publication of environmental information. ALQP emphasizes the important role of educational institutions, professional bodies and professional associations as well as the decentralization of environmental information from different departments within the organization. ALQP between organizations in different countries will be different. Zhu et al. (2008) show that there is a good relationship between organizational learning mechanism and the application of green supply chain management practices. With the above analysis, the research group built hypothesizes the relationship between NP and the level of EIR as follows: 
Hypothesis 4 (H4): ALQP has a positive relationship with the level of EIR of listed companies on Vietnam stock market.

\section{Mimetic Pressure (ALBC)}

Under the framework of institutional theory, ALBC emphasizes the effects caused by networks of behavior and social relations. When organizations have the ability to mimic the behaviors of other organizations that are closely linked or increasingly attached to them, they tend to work or track by organizations of the same scale, business sector or geographic location (DiMaggio \& Powell 1983). Zeng et al. (2012) used institutional theory to show that industries with many enterprises in the same industry participated in EIR activities and companies with better reputations were able to disclose more environmental information.

Hypothesis 5 (H5): ALBC has a positive relationship with the level of EIR of listed companies on Vietnam stock market.

\section{Active environmental strategy (CLMT)}

With the framework of uncertainty theory, Active CLMT has affects on the EIR. Chang and Deegan (2010) find that there are changes in CLMT that can encourage the management accounting system to provide information and reduce environmental uncertainty. Larrinaga-Gonzalez and Bebbington (2001) point out that when a company conducts environmental management initiatives, it requires more integrated accounting functions with CLMT. The hypothesis on the relationship between active strategy and the level of EIR is expressed as follows:

Hypothesis 6 (H6): CLMT have a positive relationship with the level of EIR of listed companies on the Vietnam Stock Market.

\section{Awareness of senior managers (NTNQT)}

Lee (2005), Kokubu et al (2005) have demonstrated that awareness of senior managers is considered an important factor in practicing environmental management accounting in particular and environmental accounting in general in Japan and Korea. The awareness of senior managers about environment will decide the selection of policies and environmental strategy in activities of enterprises. Spencer et al (2013) found that the senior management board with environmental awareness will tend to apply an accounting system to provide environmental-related information. Therefore, the authors build the next hypothesis for this relationship as follows:

Hypothesis 7 (H7): NTNQT has a positive relationship with the level of EIR of listed companies in Vietnam stock market.

\section{Industry (NCN)}

Many empirical studies around the world have demonstrated this issue, such as Deegan and Gordon (1996), Wilmshurst and Frost, (2000), Cormier and Gordon (2001). Cormier and Gordon (2001) revealed that EIR tends to be more widespread in environmentally sensitive industries such as petroleum, chemicals and paper products ... (Liu and Anbumozhi, 2009).

Hypothesis 8 (H8): Environmentally sensitive NCN have a positive relationship with the level of EIR of listed companies on the Vietnam Stock Market.

\section{Enterprises scale (QM)}

The institutional theory framework indicates that QM is the factors published by many research projects that have significant influence on EIR. The greater the enterprises scale is, the higher the likelihood of the EIR is. With abundant financial resources, high managerial and technical staff, the large enterprises will easily practice EIR to meet political and social pressures, branding under the eyes of 
community, investors. Because of these reasons, the authors show the relationship between QM and the level of EIR.

Hypothesis 9 (H9): QM has a positive relationship with the level of EIR of listed companies on Vietnam stock market.

\section{Profitability and financial leverage (KNSL and DBTC)}

Under the framework of signaling theory, the enterprises will implement EIR to express their position in the minds of investors, financial institutions ... Li et al (1997) research about environmental liabilities and realizing that the managers have an EIR strategy, environmental information tends to increase when the enterprises may cause more pollution, when stakeholders become more aware of environmental liabilities of companies. The publication of environmental information will help the enterprises gain market benefits as well as the ability to gain profits from investment in environmental improvement activities; so the enterprises have more environmental information in the report. Shane and Spicer (1983), Gelb and Zarowin (2002) provided evidence that the published information has relationship with future estimated earnings. Saha et al (2012) demonstrate a positive relationship between environmental reporting and company profits. In addition, financial leverage also has an impact on the EIR presented in the study of Zhang et al. (2008). Therefore, the authors built the following hypotheses:

Hypothesis 10 (H10): KNSL have a positive relationship with the level of EIR of listed companies on Vietnam stock market.

Hypothesis 11 (H11): DBTC has a positive relationship with the level of EIR of listed companies on the Vietnam Stock Market.

\subsection{Proposed research model}

Based on the background theory, the relevant research results, the authors have built 11 research hypotheses and shown in Table 1.

Table 1. Summary of research hypotheses

\begin{tabular}{|l|l|c|}
\hline Hypotheses & \multicolumn{1}{|c|}{ Set variables for hypotheses } & Expected sign \\
\hline H1 & X1: ALCĐ has a positive relationship with the level of EIR & + \\
\hline H2 & X2: ALBLQ has a positive relationship with the level of EIR & + \\
\hline H3 & X3: ALCP has a positive relationship with the level of EIR & + \\
\hline H4 & X4: ALQP has a positive relationship with the level of EIR & + \\
\hline H5 & X5: ALBC has a positive relationship with the level of EIR & + \\
\hline H6 & X6: CLMT has a positive relationship with the level of EIR & + \\
\hline H7 & X7: NTNQT has a positive relationship with the level of EIR & + \\
\hline H8 & X8: NCN has a positive relationship with the level of EIR & + \\
\hline H9 & X9: QM has a positive relationship with the level of EIR & + \\
\hline H10 & X10: KNSL has a positive relationship with the level of EIR & + \\
\hline H11 & X11: ĐBTC has a positive relationship with the level of EIR & + \\
\hline
\end{tabular}

At the same time, meeting the research objectives, after consulting experts, the authors would like to propose the research model as the multivariate regression model as follows:

$Y($ Level of EIR $)=\alpha 1 X 1+\alpha 2 X 2+\alpha 3 X 3+\alpha 4 X 4+\alpha 5 X 5+\alpha 6 X 6+\alpha 7 X 7+\alpha 8 X 8+\alpha 9 X 9+\alpha 10 X 10$ $+\alpha 11 X 11+\varepsilon$ 


\section{RESEARCH METHOD}

The listed companies in the manufacturing sector in Vietnam stock market is the research sample. In the process of solving research objectives, the authors use mixed research methods, which are:

Qualitative research methods are used to describe research objects, expressing concepts, characteristics, forms... of the EIR. For the purpose of deep understanding and description of the research problem, the research topic collected qualitative data by expert interviews, including those in the field of research, is conducted through interviews with indicated questions combine with flexible questions that vary according to specific circumstances and situations; so that the experts can speak freely and share their views.

Quantitative research methods to quantify the variation of the research object, verify the proposed research hypotheses, determine the factors affecting the EIR as economic, political and legal tools,.... This is a detailed analysis of the collected data to determine the correlation of the factors and thereby give specific results on the research topic.

\section{DESCRIPTION METHOD OF DATA COLLECTION}

\subsection{Describe the observed variables}

The studies on EIR is researched and developed in the world from the 70 s in many different contexts. On the basis of inheriting previous studies with expert advice in accordance with the context of Vietnam, the authors designed the observed variables to measure independent variables (factors affecting the EIR) and dependent variables (level of EIR) with 5-point Likert scale (with 1 being very disagree and 5 being very agreeable) is used to measure each aspect of the factors.

Table 2. Observed variables for factors affecting the level of environmental information reporting

\begin{tabular}{|c|c|c|c|}
\hline Factor & Observed variable & Sign & Source \\
\hline \multirow{6}{*}{$\begin{array}{l}\text { 1.Pressure of } \\
\text { coercive } \\
\text { government }\end{array}$} & $\begin{array}{l}\text { 1. Regulations on government } \\
\text { environmental reporting }\end{array}$ & ALCP 1 & Qian et al (2011) \\
\hline & 2. Tightening environmental licensing & ALCP 2 & Qian et al (2011) \\
\hline & $\begin{array}{l}\text { 3. Regulations on environmental } \\
\text { penalties }\end{array}$ & ALCP 3 & Qian et al (2011) \\
\hline & $\begin{array}{l}\text { 4. National / international } \\
\text { environmental law }\end{array}$ & ALCP 4 & Pondeville et al (2013) \\
\hline & 5. Environmental tax policy & ALCP 5 & Pondeville et al (2013) \\
\hline & $\begin{array}{l}\text { 6. Environmental regulations affect the } \\
\text { industry }\end{array}$ & ALCP 6 & Pondeville et al (2013) \\
\hline \multirow{3}{*}{$\begin{array}{l}\text { 2.Normative } \\
\text { pressure }\end{array}$} & $\begin{array}{l}\text { 7. Education and } \\
\text { development } \\
\text { skills; staff training) }\end{array}$ & ALQP 1 & $\begin{array}{l}\text { Jamila et al (2015); } \\
\text { Qian \& Burritt (2009) }\end{array}$ \\
\hline & $\begin{array}{l}\text { 8. The connection between accounting } \\
\text { and environmental departments }\end{array}$ & ALQP 2 & $\begin{array}{l}\text { Lee et al (2005); } \\
\text { Kokubu et al (2005) }\end{array}$ \\
\hline & $\begin{array}{l}\text { 9. } \text { Members of } \\
\text { associations } \\
\text { associations, ..) }\end{array}$ & ALQP 3 & $\begin{array}{l}\text { Jamila et al (2015); } \\
\text { Qian \& Burritt (2009) }\end{array}$ \\
\hline
\end{tabular}




\begin{tabular}{|c|c|c|c|}
\hline \multirow{4}{*}{$\begin{array}{l}\text { 3.Mimetic } \\
\text { Pressure }\end{array}$} & 3. The enterprises in the same industry & ALBC 1 & $\begin{array}{l}\text { Qian et al (2011), } \\
\text { Jamila et al (2015) }\end{array}$ \\
\hline & 4. Other enterprises in $\mathrm{NCN}$ & ALBC 2 & $\begin{array}{l}\text { Qian et al (2011), } \\
\text { Jamila et al (2015) }\end{array}$ \\
\hline & 5. The competitors & ALBC 3 & $\begin{array}{l}\text { Qian et al (2011), } \\
\text { Jamila et al (2015) }\end{array}$ \\
\hline & 6. Multinational organizations & ALBC 4 & Jamila et al (2015) \\
\hline \multirow{2}{*}{$\begin{array}{l}\text { 4.Community } \\
\text { pressure }\end{array}$} & $\begin{array}{l}\text { 7. The community is interested in the } \\
\text { environmental report of the } \\
\text { organization }\end{array}$ & ALCĐ1 & Qian et al (2011) \\
\hline & $\begin{array}{l}\text { 8. Community raises awareness of } \\
\text { environmental impacts }\end{array}$ & ALCĐ2 & Qian et al (2011) \\
\hline \multirow{4}{*}{$\begin{array}{l}\text { 5.Stakeholders } \\
\text { pressure }\end{array}$} & 16. Shareholders of the Company & $\begin{array}{l}\text { ALBLQ } \\
1\end{array}$ & Jamila et al (2015) \\
\hline & 17. Customers & $\begin{array}{l}\text { ALBLQ } \\
2\end{array}$ & Jamila et al (2015) \\
\hline & 18. Press and Media & $\begin{array}{l}\text { ALBLQ } \\
3\end{array}$ & Jamila et al (2015) \\
\hline & 19. Environmental organizations & $\begin{array}{l}\text { ALBLQ } \\
4\end{array}$ & Jamila et al (2015) \\
\hline \multirow{3}{*}{$\begin{array}{l}\text { Active } \\
\text { environmental } \\
\text { strategy }\end{array}$} & $\begin{array}{l}\text { 21. Environment management system - } \\
\text { ISO } 14001\end{array}$ & CLMT 1 & Walls et al (2008) \\
\hline & $\begin{array}{l}\text { 24. Position of environmental } \\
\text { information in enterprise reports }\end{array}$ & CLMT 2 & Walls et al. (2008) \\
\hline & 26. Sustainable Development & CLMT 3 & Scott (1994) \\
\hline \multirow{4}{*}{$\begin{array}{l}\text { 7. Awareness of } \\
\text { senior managers }\end{array}$} & 27. Meet legal responsibilities & $\begin{array}{l}\text { NTNQT } \\
1\end{array}$ & Bebbington et al (1994) \\
\hline & $\begin{array}{l}\text { 28. Satisfying the explanation } \\
\text { requirement }\end{array}$ & $\begin{array}{l}\text { NTNQT } \\
2\end{array}$ & Bebbington et al (1994) \\
\hline & $\begin{array}{l}\text { 29. Accurate environmental cost } \\
\text { information }\end{array}$ & $\begin{array}{l}\text { NTNQT } \\
3\end{array}$ & Spencer et al (2013). \\
\hline & $\begin{array}{l}30 . \text { Provide a viewpoint of proper and } \\
\text { reasonable operation }\end{array}$ & $\begin{array}{l}\text { NTNQT } \\
4\end{array}$ & Bebbington et al (1994) \\
\hline $\begin{array}{l}\text { 8. Enterprises } \\
\text { scale }\end{array}$ & & QM & $\begin{array}{l}\text { Deegan và Gordon } \\
\text { (1996), Patten (2002), } \\
\text { Zhang et al (2008) }\end{array}$ \\
\hline 9. Industry & & $\mathrm{NCN}$ & $\begin{array}{l}\text { Deegan and Gordon } \\
\text { (1996), Patten (1992), } \\
\text { Gray et al (2001); } \\
\text { Clarkson et al (2008); } \\
\text { P.Malarvizhi, Ranjani } \\
\text { Matta (2016) }\end{array}$ \\
\hline 10. Profitibility & & KNSL & $\begin{array}{l}\text { Deegan and Gordon } \\
\text { (1996), Neu et al. }\end{array}$ \\
\hline
\end{tabular}




\begin{tabular}{|l|l|l|l|}
\hline & & & $\begin{array}{l}\text { (1998), Zhang et al } \\
\text { (2008), Anup Kumar } \\
\text { Saha, Shahnag Akter } \\
(2012)\end{array}$ \\
\hline $\begin{array}{l}\text { 11. Financial } \\
\text { leverage }\end{array}$ & DBTC & Zhang et al (2008) \\
\hline
\end{tabular}

(Source: Summary of authors)

\subsection{Research sample size}

The reliability of the information will depend on the selected sample size, when increasing the sample size, the reliability of the information also increases. However, in practice, the choice of sample depends on a very important factor: the financial capacity and the time that the researcher can obtain. The sample size for the questionnaire survey is often determined by the empirical formula 5 times of the total number of observed variables (Hair, Anderson, Tatham and Black; 1998). In this study, the authors have 31 observed variables, the minimum sample is $5 * 31=155$ samples

The sample data on listed companies on the Vietnamese stock market in this study is taken from the ICB (industry classification benchmark) 2017. The industry classification benchmark is the sectoral system developed by Dow Jones and FTSE, developed and introduced in 2006 with 10 major industry groups, 19 industry groups, 41 branches and 114 small subsectors. ICB has gained popularity worldwide and is chosen by investors. ICB is currently used to subdivide in 73 countries such as the US, European countries and Asia Pacific with a database containing more than 70,000 companies and more than 75,000 securities codes. List of listed companies is taken by stratified method according to the corresponding ratio in the overall to 8 environment-sensitive industries on the basis of Circular 04/2012/TT_BTNMT, which is: Electricity and water and gas; Tourism and entertainment; Chemicals; Basic resources; Food and drink; Materials and construction; Medical; Car spare parts.

\subsection{Data collection}

To assess the factors affecting the level of EIR, the authors use the questionnaire survey method, send it directly or through Google Form tool to accountant, chief accountant, director who have 5 years of experience or more. Survey forms are designed with 2 parts. Part 1 deals with general information of respondents and part 2 is survey questions. Survey questions are designed around research objectives, subject to research topics to ensure comprehensiveness, to facilitate data collection and analysis. Before conducting the official survey, the research team conducted a preliminary survey with a sample of 10 manufacturing enterprises listed on the Vietnam Stock Market. The results showed that the questionnaire should add the concepts of "environmental assets, environmental liabilities, environmental revenue, environmental uncertainty" so that the survey objects can clearly identify. Survey questionnaires were sent to respondents in 170 companies listed on the Vietnamese stock market. After removing 15 invalid votes, the number of valid questionnaires used in this study is 175 votes.

\section{RESEARCH RESULT}

\subsection{Verification of the reliability of factors affecting environmental information reporting}

Study to use Cronbach's Alpha coefficient and total variable correlation coefficient in SPSS 22.0 analysis to test the reliability of observed variables and factors affecting EIR. The greater the Cronbach's Alpha coefficient is, the higher the internal consistency reliability is. According to Hair et al. (2010), the Cronbach's Alpha coefficient is 0.8 and above is good, and from 0.7 to 0.8 is usable. However, some other researchers argue that in the new research situation and the new research concept, the Cronbach's Alpha coefficient of 0.6 and above is acceptable. The corrected item - total correlation is used to eliminate unsatisfactory observed variables when the corrected item - total correlation is less than 0.3. 
In this study, observed variables of independent variables and dependent variables are selected when Cronbach's Alpha coefficient is 0.6 or higher and the the corrected item - total correlation is greater than 0.3 (Appendix 3). Cronbach's Alpha coefficients of observed variables of the level of EIR, specifically: Cronbach's Alpha coefficient for 6 variables for government ALCC is 0.878 (>0.6); Cronbach's Alpha coefficient for 3 variables for ALQP is $0.857(>0.6)$; Cronbach's Alpha coefficient for 4 variables for ALBC 0.861 ( $>0.6)$; Cronbach's Alpha coefficient for 2 variables for ALCD is $0.969(>0.6)$; Cronbach's Alpha coefficient for 4 variables for ALBLQ is $0.816(>0.6)$; Cronbach's Alpha coefficient for 3 variables for CLMT is $0.820(>0.6)$; Cronbach's Alpha coefficient for 4 high-level variables NTNQT is 0.864 ( $>0.6$ ); Cronbach's Alpha coefficient for 2 variables for profitability of $0.607(>0.6)$; Cronbach's Alpha coefficient of the 8 observed variables in the dependent variable is $0.930(>0.6)$. In addition, the corrected item - total correlation of all variables in the study model are greater than 0.3 . This shows that the observed variables in the research model are reliable.

\subsection{Exploratory Factor Analysis (EFA)}

\section{Analysis of exploratory factors for independent variables}

Results of SPSS software 22.0 when analyzing the exploratory factor EFA for independent variables (11 factors affecting the level of EIR) for KMO results $=0.756>0.5$; Sig is $0,000<0.05$; variance extracted $78,716 \%>50 \%$; factor loading of the observed variables is $>0.5$. Thus exploratory factor analysis for independent variables is appropriate, 11 independent variables explain $78.716 \%$ of data variable through 31 observed variables.

\section{Exploratory factor analysis for dependent variables}

Results of SPSS software 22.0 when analyzing the exploratory factor EFA for dependent variable (level of EIR) gives KMO results $=0.925>0.5$; Sig is $0,000<0.05$; variance extracted $68,676 \%>50 \%$, factor loading of the observed variables were $>0.5$. Thus exploratory factor analysis for dependent variables is appropriate, the dependent variable explains $68.676 \%$ of data variables through 8 observed variables

\subsection{Regression analysis}

In order to establish multivariate regression functions, it is necessary to firstly evaluate the correlation relationship between dependent and independent variables. The greater the correlation coefficient is, the closer the relationship between variables is and vice versa. Simultaneously positive correlation coefficients bring positive relationship for the pairs of variables and the negative correlation coefficients bring the negative relationship between pairs of variables.

Table 3. Regression model result

\begin{tabular}{|r|r|r|r|r|c|}
\hline Model & R & R Square & $\begin{array}{r}\text { Adjusted } \\
\text { R Square }\end{array}$ & \multicolumn{1}{c|}{ F } & Sig. \\
\hline 1 & $0,928^{\mathrm{a}}$ & 0,861 & 0,852 & 92,148 & $0,000^{\mathrm{b}}$ \\
\hline
\end{tabular}

Source: The result of SPSS 22.0 
Table 4. Regression coefficient

\begin{tabular}{|l|c|c|c|c|c|c|c|}
\hline \multirow{2}{*}{ Model } & \multicolumn{2}{|c|}{$\begin{array}{c}\text { Unstandardized } \\
\text { Coefficients }\end{array}$} & $\begin{array}{c}\text { Standardized } \\
\text { Coefficients }\end{array}$ & \multirow{2}{*}{ T } & \multirow{2}{*}{ Sig. } & \multicolumn{2}{c|}{$\begin{array}{c}\text { Collinearity } \\
\text { Statistics }\end{array}$} \\
\cline { 2 - 4 } \cline { 7 - 8 } & B & Std. Error & Beta & & & Tolerance & VIF \\
\hline (Constant) & $-2,943$ & 0,317 & & $-9,280$ & 0,000 & & \\
\hline ALCP & 0,589 & 0,038 & 0,550 & 15,694 & 0,000 & 0,692 & 1,444 \\
\hline ALQP & 0,200 & 0,023 & 0,291 & 8,624 & 0,000 & 0,749 & 1,335 \\
\hline ALBC & 0,028 & 0,025 & 0,041 & 1,100 & 0,273 & 0,624 & 1,602 \\
\hline ALBLQ & $-0,098$ & 0,026 & 0,120 & 3,835 & 0,000 & 0,873 & 1,145 \\
\hline CLMT & 0,135 & 0,025 & 0,178 & 5,285 & 0,000 & 0,749 & 1,335 \\
\hline NTNQT & 0,427 & 0,028 & 0,531 & 15,217 & 0,000 & 0,698 & 1,432 \\
\hline QM & 0,419 & 0,030 & 0,446 & 14,176 & 0,000 & 0,860 & 1,163 \\
\hline NCN & 0,173 & 0,024 & 0,215 & 7,080 & 0,000 & 0,926 & 1,080 \\
\hline KNSL & $-0,148$ & 0,035 & $-0,130$ & $-4,247$ & 0,000 & 0,901 & 1,110 \\
\hline DBTC & $-0,136$ & 0,019 & $-0,024$ &,- 721 & 0,472 & 0,763 & 1,310 \\
\hline
\end{tabular}

Source: The result of SPSS 22.0

Thus, the Sig value of F-test is $0,000<0.05$, indicating that the linear regression model is suitable for the whole. The coefficient $\mathrm{R} 2$ adjusted in Table 4.4 is 0.852 , which means that the independent variables in the model explain $85.2 \%$ of the change in the level of EIR. The model reaches a high level of conformity. - Looking at the Sig value in Table 8 , if it is less than or equal to 0.05 , these independent variables are meaningful for the dependent variable, and if it is greater than 0.05 , the variable will be rejected. Therefore the variable "ALBC" has sig 0.273 and the variable "ALBLQ" with sig is 0.472 are removed from the research model. Thus, reject the hypothesis $\mathrm{H} 2, \mathrm{H} 5$.

Analysis of Beta standardized regression coefficients in Table 8 shows the impact level of independent variables on the dependent variable (level of EIR). In the remaining nine independent variables, except for the two independent variables, "Profitability" and "Financial leverage" with a negative correlation showing the opposite relationship, the other 7 independent variables are positively correlated expressing the degree of positive impact to the level of EIR, then "ALCC government" (Beta = 0.550 ) has the strongest impact, followed by "high level NTNQT" (Beta $=0.531)$, then " QM DN "(Beta $=0,446), "$ ALQP "(Beta = 0.291)," NCN "(Beta = 0.215)," Active CLMT "(Beta = 0.178) and lowest is" ALCĐ "(Beta = 0,120). Thus, the hypotheses H1, H3, H4, H6, H7, H8, H9 are accepted. In addition, the VIF coefficient in table 4.5 of the variables is less than 2 (for research with model and the questionnaire using Likert scale) so there is no multicollinearity. So, the official regression equation is:$$
Y=-2,943+0,589 A L C P+0,200 A L Q P+0,098 A L C D+0,135 C L M T+0,427 N T N Q T+0,419
$$$$
Q M+0,173 \mathrm{NCN}-0,148 \mathrm{KNSL}-0,136 \mathrm{DBTC}+0,028 \mathrm{ALBC}-0,025 \mathrm{ALBLQ} \text {. }
$$ 


\subsection{Research results discussion}

The listed companies have published mandatory environmental information in accordance with the regulations of the Ministry of Finance for annual reports such as natural resources tax, environmental protection fee, environmental rehabilitation ... Environmental information mainly payable liabilities, assets, resource consumption and environmental costs. Most of the published environmental information is good information, only one company presents environmental violation fine information on account 811

The environmental information that is not presented in a centralized manner, scattered in the annual report also causes difficulties in collecting and supporting the decision-making of shareholders and investors. In general, "environment" is a big challenge for enterprises The level of EIR is low because the current financial and accounting framework is not comprehensive enough, it needs a separate standard to effectively deal with issues related to environmental accounting.

Table 5. Descriptive statistics on barriers to environmental information disclosure

\begin{tabular}{|l|c|c|c|c|c|}
\hline \multicolumn{1}{|c|}{ Barriers affect EIR } & Mean & Max & Min & $\begin{array}{c}\text { Standard } \\
\text { Error of } \\
\text { Mean }\end{array}$ & $\begin{array}{c}\text { Standard } \\
\text { Deviation }\end{array}$ \\
\hline 1.Afraid to change & 4.29714 & 5 & 3 & .045322 & .599561 \\
\hline 2.Low priority of environmental accounting & 4.09714 & 5 & 1 & .061011 & .807111 \\
\hline 3. Limitation of financial resources & 4.40571 & 5 & 2 & .048692 & .644134 \\
\hline $\begin{array}{l}\text { 4. Consideration of financial efficiency } \\
\text { 5. Environmental costs are negligible }\end{array}$ & 4.26857 & 5 & 3 & .048075 & .635976 \\
\hline $\begin{array}{l}\text { 6. Difficulties in collecting environmental } \\
\text { information }\end{array}$ & 4.47428 & 5 & 1 & .088711 & 1.173545 \\
\hline $\begin{array}{l}\text { 7. The uncertaincy of environment } \\
\text { 8. Lack of institutional pressure }\end{array}$ & 3.70285 & 5 & 1 & .079105 & 1.046473 \\
\hline 9. Stakeholder power & 4.17714 & 5 & 3 & .052368 & .692772 \\
\hline $\begin{array}{l}\text { 10. Shareholder power } \\
\text { 11. Lack of environmental responsibility and } \\
\text { explaination responsibility }\end{array}$ & 4.05142 & 5 & 1 & .060250 & .797038 \\
\hline $\begin{array}{l}\text { 12. Lack of integration of environmental } \\
\text { issues into strategic planning }\end{array}$ & 4.09142 & 5 & 1 & .056305 & .744856 \\
\hline $\begin{array}{l}\text { 13.Low priority on providing environmental } \\
\text { information }\end{array}$ & 3.50285 & 5 & 1 & .088361 & 1.168918 \\
\hline
\end{tabular}

Therefore, in order to improve the quality and level of EIR of listed companies, some solutions need to be implemented as follows: 
- Develop a separate framework for EIR such as ESG reporting or sustainability report based on GRI guidelines. Standards Sustainable Reporting GRI - a set of related reporting standards, allows organizations to publish report on economic, environmental and social impacts that contribute to sustainable development. This is the standard of EIR which is recognized and applied by 10 thousand organizations in 39 industries in 110 countries around the world, connecting 27 thousand sustainable development experts in the world, and 550 commitments to support at 68 countries. EIR must be compulsory for large scale enterprises such as DN VN30 group - top 30 leading enterprises in Vietnam.

- For NCN who are sensitive to the environment, enterprises should be asked to provide a brief description of environmental accounting policies, to disclose all kinds of relevant information about environment such as qualitative information (eg, environmental objects, policy, compliance), quantitative information (eg, emissions, toxic releases, pollution levels, consumption of natural resources scarcity) and environmental financial information.

- Standardize the requirements of recognition, measurement of EIR related to environmental assets, environmental costs, potential environmental liablities, environmental payables ... on the annual reports of listed companies. The lack of clear rules has contributed to the inconsistency of presenting information between the enterprises, industries, scales, etc., that leads to the fact that the other stakeholders, including agencies, investors, financial analysts and the community may consider the environmental information disclosed by companies are incomplete or unreliable.

- Strengthen the implementation of the environmental audit mechanism on the false EIR in the company report.

- Strengthening propaganda and advertising activities, praising enterprises to implement the EIR on annual reports and sustainable development reports to increase the spillover effect in awareness and practice of EIR in the listed companies in particular and the business community in general.

- Most of the studies have paid attention to large enterprises but ignored most Vietnamese business community as small and medium enterprises. So how to encourage small and medium organizations to participate in this activity. The agencies and experts need to have agendas, advertising activities targeted at small and medium-sized enterprises that help managers from small and medium organizations to identify the overall benefit of the EIR, aims to improve participation among organizations of all scale.

\section{CONCLUSIONS}

The level of EIR through annual reports of listed companies in Vietnam stock market is still low, there are significant differences between QMDN and NCN types. Most enterprises have practiced EIR in both qualitative and quantitative aspects. Except for a few large scale enterprises investing in image, content and showing separate environmental information, the majority of EIR is still at a simple level to ensure compliance with the information disclosure requirements on the stock market for listed companies.

\section{REFERENCES}

[1] Ministry of Finance (2015), Enterprise accounting regime, Finance Publisher;

[2] Le, V. L., Tran, T. T., \& Phan, L. T. (2016). The theory explains the voluntary disclosure of environmental and social information of enterprises. Accounting and Auditing, 152

[3] IFC Consulting Program in East Asia - Pacific (2016), General Guidelines Environment - Health - Safety (EHS), 194 - 206

[4] Dao Thi Loan and Nguyen Thi Hanh Duyen (2016). Environmental accounting. Current situation and application orientation in Vietnam. Journal of Accounting and Auditing, No. T5/2016 
[5] Dion, v. d. B., \& Rui, J. O. V. (2014). Environmental Disclosure Determinants in Dutch Listed Companies. R. Cont. Fin. - USP, São Paulo, 25, 68-78.

[6] Law on Environmental Protection No. 55/2014/QH13

[7] Tran Phuoc Hien (2014), Orientation to build environmental management accounting in Vietnam, Master thesis, Ho Chi Minh City, 2014;

[8] Circular 155/2015/TT-BTC dated October 6, 2015 providing for information disclosure on Vietnam stock market.

[9] Stichting Global Reporting Initiative (2013). Guidelines for GRI Sustainable Development Report.

[10] International Federation of Accountants (2005), Environmental Management Accounting, International Guidance Document, USA.

Received on February 1st, 2019

Accepted on March 25th, 2019 